\title{
Dried Rum Distillery Stillage in Laying Rations $^{1,2}$
}

\author{
Moisés Díaz-Medina and Paul F. Randel ${ }^{3,4}$
}

\begin{abstract}
Rations with 0 to $30 \%$ dried cane molasses stillage, added to a commercial layer feed were compared in two experiments using individually caged White Leghorn hens. Rations were made isonitrogenous by adding fishmeal, but differences in caloric value and content of other specific nutrients, due to stillage and fishmeal substitution, were not compensated.

In experiment 1 , the control, the commercial ration, exceeded the $30 \%$ stillage ration $(P<.01)$ in laying frequency $(81.0$ vs. $58.1 \%),(P<.05)$ weight per egg (62.3 vs. $56.5 \mathrm{~g})$, and $(P<.01) \mathrm{g}$ of feed per $\mathrm{g}$ of egg $(2.17$ vs. 3.86). The control also exceeded the $20 \%$ stillage ration $(P<.01)$ in laying frequency $(68.6 \%)$, and $(P<.05)$ in feed conversion $(3.10)$. The 5 and $10 \%$ stillage rations did not differ significantly from the control.

In experiment II, which did not include a zero-stillage ration, the laying frequencies did not differ significantly. Weight per egg was higher $(P<.05)$ with the 15 and 17.5 stillage rations $(63.0$ and $63.2 \mathrm{~g})$ than with the $20 \%$ $(59.9 \mathrm{~g})$. Feed conversion was more efficient $(P<.05)$ with the $10 \%$ ration (2.58) than with the $20 \%$ (3.13). Feed per gram of egg increased by $.048 \mathrm{~g}$ for each additional 1\% of stillage in the ration, making such addition worthless. Treatments did not affect significantly feed intake or liveweight gain. Rations with more than $10 \%$ stillage caused progressively more watery and black feces, which stained both hens and eggs. The $30 \%$ stillage ration became a sticky mass when exposed to air for several hours.

Dried stillage is well tolerated by laying hens, and perhaps with compensation for caloric dilution by addition of fat, it may be used efficiently in layer rations at levels somewhat below $20 \%$.
\end{abstract}

\section{INTRODUCTION}

In Puerto Rico enormous quantities of stillage result from the fermentation and distillation of cane molasses to produce ethyl alcohol. No use is presently made of this byproduct, and its disposal in coastal waters represents a serious source of pollution. If the dilute stillage, which represents the effluent from the distillation columns, could be condensed or dried at a cost not exceeding the value of the final product as animal feed, a useful and non-polluting method of disposal might be practical.

The chemical composition of this byproduct is extremely complex. In local stillage the inorganic fraction comprises approximately $30 \%$ of the dry matter; prominent therein are the elements $\mathrm{K}, \mathrm{Ca}, \mathrm{Mg}, \mathrm{Cl}$, and

${ }^{1}$ Manuscript submitted to Editorial Board March 28, 1977.

${ }^{2}$ Data taken from a MS thesis submitted by the senior author to the Graduate School of the Mayagüez Campus, University of Puerto Rico, June 1976.

${ }^{3}$ Agricultural Extension Agent, Naguabo, P.R.; and Nutritionist, Agricultural Experiment Station, College of Agricultural Sciences, Mayagüez Campus, University of Puerto Rico, Río Piedras, P.R.

${ }^{4}$ The authors acknowledge the contribution of Francisco B. González Rodríguez in the conduct of the metabolizability trial. 
$\mathrm{S}(5,9)$. There is little quantitative information regarding the organic fraction. Underkofler and Hickey (7) listed the principal components as reducing sugars, protein, gums, organic acids, glycerol, waxes, phenolic bodies, lignin, and glucosides. Lyman et al. (3) demonstrated the presence of relatively high concentrations of several of the essential amino acids.

Some research on the feeding of cane molasses stillage to poultry was done years ago. Bearse et al. (1) found dried stillage in the form of a commercial product, Vacatone ${ }^{5}$, to be a good source of riboflavin for chicks when included at $2.5 \%$ of the ration. Wakelam and Jeffe (8) reported unidentified growth factor activity for chicks in a byproduct of industrial alcohol production by yeast fermentation of blackstrap molasses. However, no reports have been found concerning the use of stillage at high levels as a major source of nutrients.

Research is needed to establish the nutritional value of processed stillage, without which an economic evaluation of its possible use in the feed industry cannot be made. The present study constitutes the first such work initiated with poultry in Puerto Rico.

\section{MATERIALS AND METHODS}

Two experiments were conducted at the Lajas Substation using White Leghorn hens of the Kimber strain. The birds were individually housed in wire cages located above oxidation tanks, in a structure having side walls covered with Saran and wire screening.

Experiment I began in May 1975 and utilized 50 hens to test rations containing $0,5,10,20$, and $30 \%$ of dehydrated stillage. The basal ration was a medicated commercial feed for layers that was purchased in the form of crumbles and ground in a hammer mill through a 6.35 mm screen.

Stillage was obtained from commercial distilleries and processed at the Rum Pilot Plant of the Agricultural Experiment Station in Río Piedras. Dried stillage was stored in plastic bags within sealed drums because of its extreme hygroscopicity. It was ground in a hand mill immediately prior to incorporation into the rations.

The five rations were formulated to be isonitrogenous by the progressive addition of tuna fishmeal in substitution for commercial feed at increasing levels of dried stillage. However, no compensation was made for differences in caloric value or in content of other specific nutrients due to addition of stillage and fishmeal. Dry matter content

\footnotetext{
${ }^{5}$ Trade names are used in this publication solely for the purpose of providing specific information. Mention of a trade name does not constitute a guarantee or warranty of equipment or materials by the Agricultural Experiment Station of the University of Puerto Rico or an endorsement over other equipment or materials not mentioned.
} 
of the rations was determined by oven drying of samples at $70^{\circ} \mathrm{C}$ crude protein by Kjeldahl procedure and of several major mineral elements by the method of Greweling (2). Table 1 shows ration formulas and chemical compositions. Feed was offered daily to each hen in an amount moderately exceeding consumption.

Egg production was recorded daily and individual egg weights were taken on two consecutive days each week. The birds were weighed individually on the first and last days of the comparison period, which was of 42 days duration.

TABLE 1. - Percentage formula and chemical composition of the rations used in the two experiments

\begin{tabular}{|c|c|c|c|c|c|c|c|c|c|c|}
\hline & \multicolumn{10}{|c|}{ Level of stillage in the ration (percent) } \\
\hline & $0^{\prime}$ & $5^{\prime}$ & $10^{\prime}$ & $10^{2}$ & $12.5^{2}$ & $15^{2}$ & $17.5^{2}$ & $20^{2}$ & $20^{1}$ & $30^{\prime}$ \\
\hline \multicolumn{11}{|l|}{ Formula } \\
\hline Commercial feed & 100 & 93.7 & 87.7 & 86.2 & 83.1 & 80.0 & 76.9 & 73.9 & 75.3 & 63.0 \\
\hline Dried stillage & 0 & 5.0 & 10.0 & 10.0 & 12.5 & 15.0 & 17.5 & 20.0 & 20.0 & 30.0 \\
\hline Fishmeal & 0 & 1.3 & 2.3 & 2.8 & 3.4 & 4.0 & 4.6 & 5.1 & 4.7 & 7.0 \\
\hline Ground limestone & 0 & 0 & 0 & 1.0 & 1.0 & 1.0 & 1.0 & 1.0 & 0 & 0 \\
\hline \multicolumn{11}{|c|}{ Chemical composition } \\
\hline Dry matter & 89.9 & 90.1 & 91.2 & 93.4 & 92.8 & 93.0 & 93.0 & 93.0 & 91.1 & 92.1 \\
\hline Crude protein & 14.9 & 15.1 & 15.8 & 16.3 & 16.7 & 16.4 & 16.8 & 16.8 & 15.2 & 15.0 \\
\hline $\mathrm{Ca}$ & 4.19 & 3.84 & 3.01 & 4.10 & 4.16 & 4.09 & 3.85 & 3.98 & 3.43 & 3.80 \\
\hline$P$ & .53 & .59 & .64 & .68 & .75 & .74 & .84 & .75 & .86 & .80 \\
\hline K & 1.13 & 1.69 & 2.33 & 2.55 & 2.96 & 3.33 & 3.56 & 3.87 & 3.28 & 4.58 \\
\hline $\mathrm{Mg}$ & .28 & .37 & .46 & .51 & .54 & .61 & .64 & .70 & .63 & .88 \\
\hline $\mathrm{Na}$ & .21 & .24 & .25 & .23 & .23 & .24 & .27 & .27 & .30 & .35 \\
\hline
\end{tabular}

' Ration used in the first experiment.

${ }^{2}$ Ration used in the second experiment.

The experimental design was randomized blocks. The 10 blocks were formed on the basis of egg production during a preliminary period of 9 days. The five best layers were assigned to block 1 , the next best quintet to block 2, and so on. The ration fed during the preliminary period contained an intermediate level of dried stillage. The data were treated by analysis of variance and multiple range test (6).

Experiment II was similar in most respects. It began about one month after the conclusion of Experiment I, and used 75 hens in 15 blocks, to test rations containing $10,12.5,15,17.5$, and $20 \%$ of dried stillage (table 1). A ration without stillage was fed during the 12-day preliminary period, after which an attempt was made to begin the comparison period with only 2 days for adjustment to the rations. However, egg production dropped sharply; thus it was necessary to recommence the comparison period 2 weeks later, when the hens were adjusted to their respective rations after which it lasted 50 days. 


\section{RESULTS AND DISCUSSION}

Table 2 shows the principal results of the two experiments. In the first experiment, there was a marked reduction in rate of lay as the percentage of dried stillage in the ration increased from 0 to 30 . However, the 5 and $10 \%$ stillage rations were not significantly inferior to the control. The $20 \%$ stillage ration was inferior $(\mathrm{P}<.01)$ to the control, but not to the 5 and $10 \%$ rations. The $30 \%$ stillage ration was inferior $(\mathrm{P}<.01)$ to all the others. In the second experiment, rations containing from 10 to $20 \%$ stillage did not differ significantly from one another in laying frequency. The 10 and $20 \%$ stillage rations of experiment I resulted in higher mean percentages than the same levels of stillage in experiment II. This might be ascribed to aging of the hens

TABLE 2. - Laying percentage, individual egg weight, egg production by weight, food intake, feed to egg conversion, and liveweight gain during experiments I and II

\begin{tabular}{|c|c|c|c|c|c|c|c|c|}
\hline \multirow[b]{2}{*}{$\begin{array}{l}\text { Level } \\
\text { of } \\
\text { stillage } \\
\text { in } \\
\text { ration }\end{array}$} & \multirow[b]{2}{*}{$\begin{array}{c}\text { Eggs } \\
\text { laid/ } \\
100 \\
\text { hen } \\
\text { days }\end{array}$} & \multirow[b]{2}{*}{$\begin{array}{c}\text { Weight/ } \\
\text { egg }\end{array}$} & \multirow[b]{2}{*}{$\begin{array}{l}\text { Daily } \\
\text { egg pro- } \\
\text { duction, } \\
\text { weight }\end{array}$} & \multicolumn{2}{|c|}{ Daily food intake } & \multirow{2}{*}{$\begin{array}{c}\text { Food } \\
\text { conver- } \\
\text { sion: } \\
\text { weight } \\
\text { feed } \\
\text { weight } \\
\text { egg }\end{array}$} & \multirow[b]{2}{*}{$\begin{array}{l}\text { Daily } \\
\text { live- } \\
\text { weight } \\
\text { gain/ } \\
\text { hen }\end{array}$} & \multirow[b]{2}{*}{$\begin{array}{c}\text { Average } \\
\text { live- } \\
\text { weight/ } \\
\text { hen }\end{array}$} \\
\hline & & & & $\begin{array}{l}\text { per } \\
\text { hen }\end{array}$ & $\begin{array}{c}\text { as } \\
\text { percent } \\
\text { live } \\
\text { weight }\end{array}$ & & & \\
\hline$\%$ & $\%$ & $G$ & $G$ & $G$ & $\%$ & $G / G$ & G & $G$ \\
\hline \multicolumn{9}{|c|}{ Experiment I } \\
\hline 0 & $81.0 \mathrm{a}^{1}$ & $62.3 \mathrm{a}$ & $50.2 \mathrm{a}$ & $110 \mathrm{a}$ & $6.35 \mathrm{a}$ & $2.17 \mathrm{a}$ & $-0.23 a$ & 1725 \\
\hline 5 & $77.1 \mathrm{ab}$ & $59.0 \mathrm{ab}$ & $45.5 \mathrm{ab}$ & $118 \mathrm{a}$ & $6.55 \mathrm{a}$ & $2.66 \mathrm{ab}$ & $.15 \mathrm{a}$ & 1805 \\
\hline 10 & $75.2 \mathrm{ab}$ & $58.5 \mathrm{ab}$ & $44.1 \mathrm{ab}$ & $115 \mathrm{a}$ & $7.11 \mathrm{a}$ & $2.91 \mathrm{ab}$ & $-.28 \mathrm{a}$ & 1622 \\
\hline 20 & $68.6 \mathrm{~b}$ & $60.1 \mathrm{ab}$ & $41.2 \mathrm{~b}$ & $118 \mathrm{a}$ & $6.87 \mathrm{a}$ & $3.10 \mathrm{bc}$ & $1.11 \mathrm{a}$ & 1720 \\
\hline 30 & $58.1 \mathrm{c}$ & $56.5 \mathrm{~b}$ & $33.1 \mathrm{c}$ & $115 \mathrm{a}$ & $6.73 \mathrm{a}$ & $3.86 \mathrm{c}$ & $.53 \mathrm{a}$ & 1702 \\
\hline \multicolumn{9}{|c|}{ Experiment II } \\
\hline 10 & $70.8 \mathrm{a}$ & $62.6 \mathrm{ab}$ & $44.1 \mathrm{a}$ & 113 a & $6.49 \mathrm{a}$ & $2.58 \mathrm{a}$ & $.63 \mathrm{a}$ & 1736 \\
\hline 12.5 & $65.4 \mathrm{a}$ & $62.3 \mathrm{ab}$ & $40.6 \mathrm{a}$ & $112 \mathrm{a}$ & $6.42 \mathrm{a}$ & $2.92 \mathrm{ab}$ & $1.12 \mathrm{a}$ & 1739 \\
\hline 15 & $67.6 \mathrm{a}$ & $63.0 \mathrm{a}$ & $42.6 \mathrm{a}$ & $112 \mathrm{a}$ & $6.45 \mathrm{a}$ & $2.67 \mathrm{ab}$ & $.74 \mathrm{a}$ & 1671 \\
\hline 17.5 & $67.4 \mathrm{a}$ & $63.2 \mathrm{a}$ & $42.6 \mathrm{a}$ & $120 \mathrm{a}$ & $6.85 \mathrm{a}$ & $2.88 \mathrm{ab}$ & $1.27 \mathrm{a}$ & 1756 \\
\hline 20 & $65.1 \mathrm{a}$ & $59.9 \mathrm{~b}$ & $39.1 \mathrm{a}$ & $118 \mathrm{a}$ & $6.97 \mathrm{a}$ & $3.13 \mathrm{~b}$ & $.49 \mathrm{a}$ & 1689 \\
\hline
\end{tabular}

${ }^{1}$ Values in columns followed by one or more letters in common do not differ significantly at the .05 level.

with the attendant gradual decline in egg production. These hens had been in production for 9 to 10 months by the end of the second experiment.

Significant differences $(\mathrm{P}<.05)$ between treatments in individual egg weight were: the $30 \%$ stillage ration was inferior to the control in experiment $\mathrm{I}$ and the $20 \%$ ration was inferior to the 15 and $17.5 \%$ rations in experiment II (table 2). However, all treatments resulted in adequate mean egg size. In total egg weight production, the $30 \%$ stillage ration was inferior $(P<.01)$ to the control, the 5 and $10 \%$ 
rations, and $(\mathrm{P}<.05)$ to the $20 \%$ ration, while the latter was inferior $(\mathrm{P}<.05)$ to the control in experiment $\mathrm{I}$. In the following trial, there were no significant differences.

Daily feed intake, whether expressed per hen or as a percentage of liveweight, did not differ significantly between treatments in either experiment (table 2). Means observed in this study agree well with normal feed consumption by laying hens (4). Thus the addition of stillage to these rations did not adversely affect palatability or voluntary intake.

Feed conversion was the variable most affected by inclusion of stillage in the rations (table 2). In experiment I the $20 \%$ stillage ration was inferior $(\mathrm{P}<.05)$ to the control, while the $30 \%$ ration was inferior $(\mathrm{P}<.01)$ to the control, and to the $5 \%$ and $(\mathrm{P}<.05) 10 \%$ rations. In experiment II the $20 \%$ ration was inferior $(\mathrm{P}<.05)$ to the $10 \%$ ration. A linear regression analysis was used to further define the relationship between feed conversion and stillage level in the ration. Individual regressions for each of the two experiments did not differ significantly; thus a common regression was computed as follows: $Y=2.22+.048 X$, where $Y$ is feed conversion and $X$ is percentage dried stillage in the ration (fig. 1). The highly significant $(\mathrm{P}<.01)$ regression coefficient (with a standard error of .0065) signifies that for each increase of $1 \%$ stillage in the ration there was a corresponding increase of .048 $\mathrm{g}$ in feed consumed per $g$ of egg produced. Thus, addition of stillage did not spare other ration ingredients, but, in fact, caused the hens to consume more of the latter per unit of egg produced. Under these conditions feeding of stillage would be of no nutritional or economic advantage.

Mean daily gain or loss of liveweight was slight in all cases and there were no significant differences between treatments in either experiment (table 2). Average liveweight, 1/2 (initial weight, + final weight), did not differ markedly among treatments, though this variable was not analyzed statistically.

A progressively severe condition of black and watery excrement was noted in hens which consumed rations containing more than $10 \%$ stillage. This diarrhetic effect was not a serious health problem, at least not for the duration of these experiments, as appetite and liveweight remained normal and the birds did not present a sickly appearance. Only one hen died during this study and that in the control treatment. Though benign healthwise, the watery excretions were a nuisance, staining a considerable number of eggs and tending to soil hens, cages, and surroundings. Another management problem with the $30 \%$ stillage ration was the formation (within a few hours) of a compact and sticky mass in the feeder. Twenty percent stillage also caused some problem in this regard, though more so in the first experiment than in the second. 
Several possible causes can be suggested to explain the adverse effects of the higher stillage levels on laying performance and of all stillage levels on feed conversion. There was probably a direct stress involving renal hyperfunction necessitated by the extra salt load. Another possibility is decreased intestinal absorption due to the diarrhetic condition. However, this is not supported by results of a preliminary metabolizability trial with the five rations of experiment II. Five other hens, fed a constant $110 \mathrm{~g}$ daily, were used in a $5 \times 5$ latin square with 1 week experimental periods. Metabolizability of dry matter in

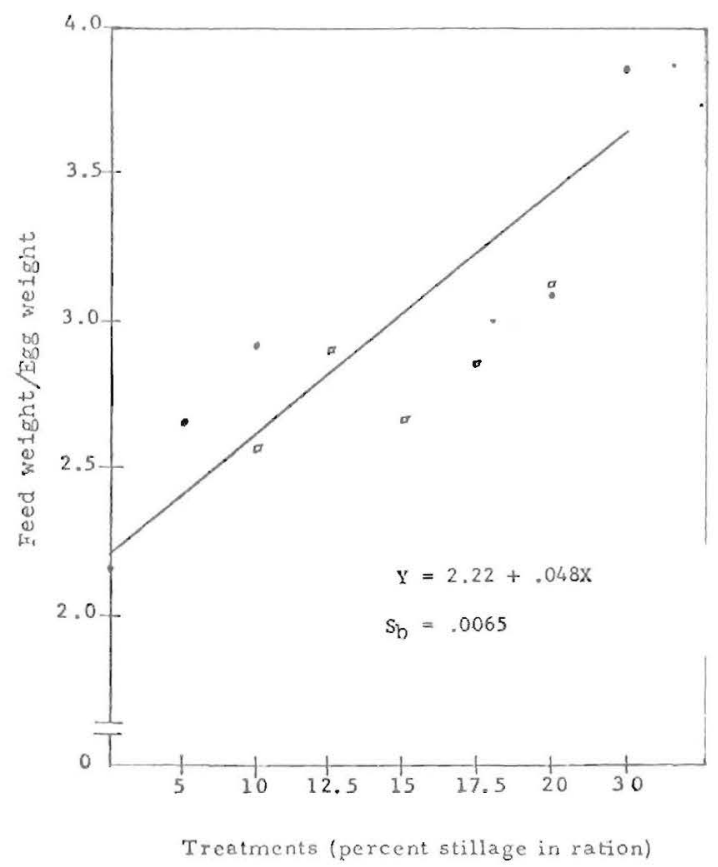

Fig. 1. - Regression of feed conversion on content of stillage in the ration.

rations with $10,12.5,15,17.5$, and $20 \%$ stillage was $70.3,71.5,69.1$, 70.3 , and $70.0 \%$, respectively. Additional work, including determination of metabolizability of specific nutrients and calories, is needed to confirm these initial observations. Finally, by diluting the calories of the ration with inorganic matter, stillage inclusion reduced consumption of productive energy. Hens fed the rations with stillage might have compensated by increasing intake, but though they ate normally, they failed to compensate for caloric dilution. Addition of fat with the stillage to maintain isocaloric rations should prevent this adverse effect. 


\section{RESUMEN}

Dos experimentos con gallinas Liornas blancas se efectuaron para evaluar raciones que contenían de 0 a $30 \%$ de mosto deshidratado. Este, obtenido de melaza fermentada, se mezcló con un alimento comercial para ponedoras. El tratamiento testigo fue el alimento comercial puro. Las gallinas se alojaron en jaulas individuales.

Las raciones se isonitrogenizaron añadiéndoles harina de atún, pero las diferencias en valor calórico y el contenido en otros nutrimentos no se compensaron.

En los dos experimentos se usaron bloques distribuidos al azar, con 10 gallinas por tratamiento en el primero y 15 en el segundo. El período de comparación fue de 42 días en el primer experimento y de 50 en el segundo.

En la primera prueba, el tratamiento testigo - la ración comercial - superó al tratamiento de $30 \%$ de mosto $(\mathrm{P}<.01)$ en frecuencia de postura $(81.0$ contra $58.1 \%$ ), $(\mathrm{P}<$ $.05)$ peso medio del huevo $(62.3$ contra $56.5 \mathrm{~g})$ y $(\mathrm{P}<.01)$ gramos de alimento por gramo de huevo (2.17 contra 3.68). El testigo también superó al tratamiento de $20 \%$ de mosto $(\mathrm{P}<.01)$ en frecuencia de postura $(68.6 \%)$ y $(\mathrm{P}<.05)$ en la transformación del alimento en postura (3.10). Las raciones con 5 y $10 \%$ de mosto no difirieron significativamente de la testigo. En la segunda prueba, que no incluyó ración sin mosto, las frecuencias de postura $(70.6$ a $65.1 \%$ ) en los niveles de $10,12.5,15,17.5$ y $20 \%$ no difirieron significativamente.

El peso medio del huevo fue mayor $(\mathrm{P}<.05)$ en las raciones de 15 y $17.5 \%$ de mosto $(63.0$ y $63.2 \mathrm{~g})$ que en la de $20 \%$ (59.9 g). La transformación del alimento fue más alta $(\mathrm{P}<.05)$ en la ración con $10 \%$ de mosto $(2.58)$ que en la que contenía $20 \%$ (3.13). La cantidad de alimento por gramo de huevo aumentó $.048 \mathrm{~g}$ con cada adición de $1 \%$ de mosto a la ración, lo cual no justifica la sustitución. Los tratamientos no afectaron el consumo de alimento ni la ganancia de peso vivo. El consumo de raciones con más de $10 \%$ de mosto produjo excremento progresivamente más acuoso y negruzco, el cual manchó tanto a las gallinas como a los huevos. La ración con $30 \%$ de mosto, y en menor grado la de $20 \%$, se convirtieron en una masa pegajosa al exponerlas al aire por varias horas.

Las gallinas toleran bien el mosto deshidratado, y tal vez compensando con grasa la reducción de calorías, se podría utilizar eficientemente a niveles bajo el $20 \%$ de la ración.

\section{LITERATURE CITED}

1. Bearse, G. E., McClary, C. F., and Miller, V.L., 1942. "Vacatone" in chick starting rations, West Wash. Agric. Exp. Stn. Rep. for year ending March 1940, (from Chem. Abs. 36: 5280.)

2. Greweling, T., 1962. An extractive procedure for the determination of total calcium, magnesium, and potassium in plant tissue, J. Agric. Food Chem. 10: 138.

3. Lyman, C. M., Kuiken, K. A., and Hale, F., 1956. Essential amino' acids content of farm feed, J. Agric. Food Chem. 4: 1008.

4. National Research Council, 1971. Nutrient requirements of poultry, 6th ed., Nat. Acad. Sci., Washington, D.C.

5. Pérez-Escolar, R., 1962. The soil conditioning properties of blackstrap molasses and rum distillery slops, PhD. Thesis, Rutgers University, New Brunswick, N. J,

6. Snedecor, G. W., and Cochran, W. G., 1967. Statistical Methods, 6th ed., Iowa State Univ. Press, Ames, Iowa.

7. Underkofler, L. A., and Hickey, J., 1954. Industrial Fermentations, Chemical Publishing Co., New York.

8. Wakelam, J. A., and Jaffe, W. P., 1961. Unidentified chick growth factors in fermentation by-products, J. Sci. Food Agric. 12: 335.

9. Water Quality Office, 1971. Disposal of rum distillery wastes, Environmental Protection Agency, Project WPD-226-01. 